\title{
A Study of Blood Donor Demographic Features and an Assessment of Blood Donor Satisfaction Level in the Process of Donation
}

\author{
Deepa Narayanan ${ }^{1}$, Archana Rajan ${ }^{2}$ \\ ${ }^{1}$ Department of Transfusion Medicine, Government Medical College, Kozhikode, Kerala, India. \\ 2Department of Transfusion Medicine, Government Medical College, Kozhikode, Kerala, India.
}

\section{ABSTRACT}

\section{BACKGROUND}

Donor satisfaction is important to increase the number of repeat voluntary donors. This will help in retaining the blood donors. Repeat donors are screened regularly so they are safe donors. Understanding demographic features of donors helps to know which group of people are reluctant to donate blood. Increasing awareness about blood donation in such groups can increase the donor pool of a country. We wanted to evaluate the donor demographic features and donor satisfaction.

\section{METHODS}

This was a cross sectional study. 1500 consecutive donors were studied. Blood donors were given a questionnaire with questions on demographics features and their satisfaction level after blood donation. Questions were in English and Malayalam. Donors who were willing to answer the questionnaire were studied. Donor demographic features and donor satisfaction were studied.

\section{RESULTS}

Majority of donors were males 1466 (97.73\%). Females were only $34(2.27 \%)$ of total blood donors. Majority of blood donors were repeat donors 820 (54.7\%). Number of first-time donors was 680 (45.3\%). Voluntary donors formed 62.13\% (932 numbers) of our donors. Replacement donors formed 37.87\% (568 numbers) of our donors. Majority of donors had an education level of up to school level (56.7\%), graduates were $39.5 \%$ of donors and postgraduates formed 3.8 percentage of donor population.

\section{CONCLUSIONS}

This study helps us to understand a group of people which needs more awareness regarding blood donation like persons above 35 years of age and women. Blood banks can take steps to improve donor satisfaction so that every donor feels a higher level of satisfaction. Fear adversely affects donor satisfaction level so by proper predonation counselling, fear of donors should be decreased.

\section{KEY WORDS}

Blood Donor, Demographic, Satisfaction
Corresponding Author: Dr. Deepa Narayanan, Assistant Professor, Department of Transfusion Medicine, Government Medical College, Kozhikode, Kerala, India. E-mail: drdeepa2@gmail.com

DOI: $10.14260 / j e m d s / 2019 / 834$

Financial or Other Competing Interests: None.

How to Cite This Article:

Narayanan D, Rajan A. A study of blood donor demographic features and an assessment of blood donor satisfaction level in the process of donation. J. Evolution Med. Dent. Sci. 2019;8(51):3850-3852, DOI: $10.14260 /$ jemds/2019/834

Submission 02-11-2019,

Peer Review 07-12-2019,

Acceptance 10-12-2019,

Published 23-12-2019. 


\section{BACKGROUND}

There is an increasing demand for blood due to increase in number of surgeries like surgery for malignancies, polytrauma, cardiothoracic surgeries and also due to increased demand for haematology patients. Blood banks meets the demand for blood through replacement and voluntary donors. Blood bank has responsibility of providing adequate blood as well as safe blood to patients.

Replacement donors are friends or relatives of patients who donate blood for planned surgeries or on urgent needs for a particular patient. Voluntary donors are donors who donate blood voluntarily without receiving any remuneration. They are not friends or relatives of the patient. In our country replacement donors provide most of the blood to blood banks. Replacement donors. May sometimes hide diseases. So Voluntary donors are considered to be the safest donors. ${ }^{1}$ NACO is organizing various activities in India for encouraging voluntary donation and thereby increasing donation of safe blood. Encouragement of voluntary blood donation provides safe blood to the public. It also makes sure availability of blood all the times. It helps in providing blood at affordable rates. ${ }^{1}$ in our hospital which is government hospital blood is provided free of cost to all patients, so retaining of voluntary donors is very important.

Government developed national blood policy in 2002 which provide support to all blood banks by national blood transfusion council. ${ }^{1}$ Blood is always lifesaving for the patient. Family members of the patient will be willing to pay money to a person who gives blood to the patient. So, if the blood banks, National AIDS control society and government is not vigilant there can be re-emergence of paid donors.

Most of the time people donate blood because of the selfsatisfaction they receive from blood donation. The satisfaction can be increased if the environment of blood bank is made pleasant donor receives adequate counseling before blood donation and donor does not have any experiences like fainting, or pain during the donation process. Donor satisfaction is important to increase the number of repeated voluntary donors. This will help in retaining the blood donors and increase the number of repeat donors. Repeat donors are screened regularly so they are considered to be safe donors. Studies from different parts of India shows that majority of blood is obtained from voluntary donors and replacement donors. ${ }^{2,3,4}$

Understanding demographic features of donors and comparing it with other studies helps to know which group of people are reluctant to donate blood in our area. This means donor motivational activities are not reaching such groups. Directing donor motivational activity towards such group will increase the number of voluntary donors. Increasing awareness about blood donation in such groups can increase the voluntary donor pool of our area.

Behavioural pattern of donors depend on demographic features some studies show that older age group donors are more likely to come for repeat donations ${ }^{5}$. Depending on demographic profile donors' experiences various obstacles in blood donation. ${ }^{6}$ understanding demographic profile helps in planning motivational activities specific for each group.

\section{METHODS}

This is a cross sectional study. Study is conducted in donors donating blood in the Department of Transfusion Medicine of Govt. Medical College Kozhikode Kerala. Study period was of one-month (December 2017) 1500 consecutive donors were studied. Blood donors were selected by doctors and counsellors as per selection criteria based on NACO guidelines. ${ }^{1}$ Only those donors who were selected for blood donation were included in the study. Donors were given a questionnaire with questions on demographics features and their satisfaction level after blood donation. Questions were in English and Malayalam. Donors who were willing to answer the questionnaire and completely filled the questionnaire were studied. Donor demographic features like age, sex, educational status, voluntary or replacement donation, first time/repeated donation were studied. Donor satisfaction was marked using Likert's scale. The scale was validated Donors were asked to rate the satisfaction in the process of blood donation as 1 (Very Good), 2 (Good), 3 (Satisfactory), 4 (Not Good) and 5 (Poor).Relationships of donor satisfaction with fear before blood donation was studied.

\section{Statistical Analysis}

The data was collected and analysed using statistical chi square test, $p<0.05$ statistically significant. Data was entered in Microsoft excel and analysis was done using SPSS Ver. 22.

\section{RESULTS}

Majority of donors were males 1466 (97.73\%). Females formed were only 34 (2.27\%). Majority of blood donors were repeat donors 820 (54.7\%). Number of first-time donors were 680 (45.3\%).Voluntary donors formed 62.13\% (932 numbers) of our donors. Replacement donors formed $37.87 \%$ (568 numbers) of our donors. Majority of donors had education level up to school level 56.7\%, graduates formed $39.5 \%$ of donors and postgraduates formed 3.8 percentage of donor population. 60. 8 percentage of donors showed high level of satisfaction. 28.8 percent of donors showed medium level of satisfaction. 10.4 percentage showed low level of satisfaction. Donor satisfaction level showed significant difference in persons with fear and without fear before blood donation. Patient with fear experienced lesser satisfaction levels.

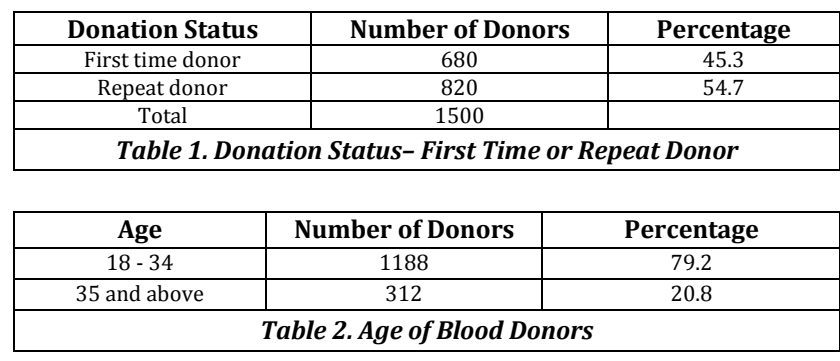




\begin{tabular}{|c|c|c|}
\hline Education Level & Number of Donors & Percentage \\
\hline School level & 851 & 56.7 \\
\hline graduation & 592 & 39.5 \\
\hline Post-graduation & 57 & 3.8 \\
\hline \multicolumn{3}{|c|}{ Table 3. Educational Status } \\
\hline
\end{tabular}

\begin{tabular}{|c|c|c|}
\hline & Number of Donors & Percentage \\
\hline Fear before blood donation & 116 & $7.7 \%$ \\
\hline No fear before blood donation & 1384 & $92.3 \%$ \\
\hline Total & $\mathbf{1 5 0 0}$ & $\mathbf{1 0 0} \%$ \\
\hline \multicolumn{2}{|c|}{ Table 4. Fear before Blood Donation } \\
\hline
\end{tabular}

\begin{tabular}{|c|c|c|}
\hline & Number of Donors & Percentage \\
\hline 1 Very good & 155 & 10.3 \\
\hline 2 Good & 756 & 50.4 \\
\hline 3 Satisfactory & 432 & 28.8 \\
\hline 4 Not good & 146 & 9.7 \\
\hline 5 Poor & 11 & 0.7 \\
\hline \multicolumn{3}{|c|}{ Table 5. Donor Satisfaction } \\
\hline
\end{tabular}

\begin{tabular}{|c|c|c|c|c|c|}
\hline & \multicolumn{5}{|c|}{ Donor Satisfaction Level } \\
\hline & 1 Very Good & 2 Good & 3 Satisfactory & 4 Not Good & 5 Poor \\
\hline Fear & 2 & 78 & 8 & 26 & 2 \\
\hline No fear & 153 & 678 & 424 & 120 & 9 \\
\hline Total & 155 & $\mathbf{7 5 6}$ & 432 & 146 & 11 \\
\hline Table 6. Relation of Donor Satisfaction with Fear. p value <0.0001 \\
\hline
\end{tabular}

\section{DISCUSSION}

Study of demographic features helps us in understanding the type of population coming for blood donation. This study shows that young donors less than 35 years of age are about 79.2 percentage of donor population. This is quite similar to other studies from India.,3,4 While some study from US, Canada shows that above 40 age group donors form equal or majority of donor population.5,6,7,8 One of the factors responsible for this may be due to increase awareness about blood donation among youth. This awareness was created by national AIDS control society. But there still remains large group of people of age 35 to 60 years unexploited for blood donation.

In our study females formed only 2.27 percentages of blood donors. Other studies from India also showed similar results. In study by $\mathrm{N}$ Rajendra et al showed 83.7 percent were males. ${ }^{3}$ More than 95 percentage of donors were males in study by Unnikrishnan et al in south coastal India. ${ }^{2}$ Study from Kolkata by S Duttaetal showed females formed 9. 32 percentage of donor population. ${ }^{9}$ Another study from Kolkata also showed similar results. ${ }^{10}$ Study from Nigeria also majority of donors were males. ${ }^{11}$ Females formed nearly $50 \%$ of donors in study from Europe.

Majority of donors were repeat donors in our study. The study of donors in south coastal India majority of donors were repeat donors. ${ }^{2}$ Study conducted in china majority of donors were first time donors. ${ }^{12}$

In our study majority of donors were voluntary. Majority of donors were replacement, 3,4 in other studies from India. Study by Christopher R France et al had shown donor anxiety decreases blood donor retention. ${ }^{13}$ Our study showed that donor fear before blood donation decreases donor satisfaction.

\section{CONCLUSIONS}

This help us to understand a group of people which needs more awareness about blood donation like persons above 35 years of age and women. Blood banks can take steps to improve donor satisfaction so that every donor feels higher level of satisfaction. Fear adversely affects donor satisfaction level; so, by proper pre-donation counselling, fear of donors should be decreased.

\section{REFERENCES}

[1] National AIDS Control Organization: Voluntary Blood Donation Program -an Operational Guideline. Ministry of Health and Family Welfare 2007.

[2] Unnikrishnan B, Rao P, Kumar N, et al. Profile of blood donors and reasons for deferral in coastal South India. Australas Medical Journal 2011;4(7):379-85.

[3] Rajendra N, Madapura PV. Study of blood donor profile in a blood bank attached to a medical college hospital - a retrospective study. Pathology Update: Trop J Path Micro 2017;3(4):406-11.

[4] Rawat V, Bhatt U, Singhai M, et al. Prevalence of hepatitis $\mathrm{C}$ virus infection among blood donors of Kumaon region of Uttarakhand. Indian J Med Microbiol 2013;31(3):3134.

[5] Shaz BH, James AB, Hillyer KL, et al. Demographic patterns of blood donors and donations in a large metropolitan area. J Natl Med Assoc 2011;103(4):351-7.

[6] Charbonneau J, Cloutier MS, Carrier E. Why do blood donors lapse or reduce their donation's frequency? Transfusion Med Rev 2016;30(1):1-5.

[7] Charbonneau J, Cloutier MS, Carrier E. Whole blood and apheresis donors in Quebec, Canada: demographic differences and motivations to donate. Transfusion and Apheresis Science 2015;53(3):320-8.

[8] Nguyen DD, Devita DA, Hirschler NV, et al. Blood donor satisfaction and intention of future donation. Transfusion 2008;48(4):742-8.

[9] Dutta S. Profile and awareness of blood donors: A study in blood bank of a tertiary care hospital of Kolkata. Int J Pharma Sci \& Res 2016;7(9):3881-6.

[10] Halder D, Majundar KK, Karir S, et al. Analysis of profile in blood donors in a blood bank of a private medical college of Kolkata. International Journal of Community Medicine and Public Health 2017;4(10):3899-902.

[11] Ugwu AO, Madu AJ, Efobi CC, et al. Pattern of blood donation and characteristics of blood donors in Enugu, Southeast Nigeria. Niger J Clin Pract 2018;21(11):143843.

[12] Wu H, Wang Yu, Gong P, et al. Diverse genotypes of Hepatitis C virus in voluntary blood donors in Shanghai, China. Hepatitis Monthly 2017;17(6):e13160.

[13] France CR, France JL, Wissel ME, et al. Donor anxiety, needle pain and syncopal reactions combine to determine retention: a path analysis of two-year donor return data. Transfusion 2013,53(9):1992-2000. 